\title{
Is late-onset Attention Deficit Hyperactivity Disorder (ADHD) a valid diagnosis in adults?
}

\author{
O Transtorno de Déficit de Atenção e Hiperatividade (TDAH) \\ de início tardio é um diagnóstico válido em adultos?
}

\section{Mauro Xavier Netoํ, Sofia Amaral Medeiros², Luiza de Campos³, Renério Fráguas Junior ${ }^{4}$}

Xavier M, Medeiros SA, Campos L, Fráguas Jr R. Is late-onset Attention Deficit Hyperactivity Disorder (ADHD) a valid diagnosis in adults? / O Transtorno de Déficit de Atenção e Hiperatividade (TDAH) de início tardio é um diagnóstico válido em adultos? Rev Med (São Paulo). 2018 jan.-fev.;97(1):71-80.

\begin{abstract}
INTRODUCTION: The current Attention Deficit Hyperactivity Disorder (ADHD) paradigm understands it as a childhood-onset neurodevelopmental disorder that can persist into adult life. However, it has been raised the possibility of a lateonset ADHD syndrome. OBJECTIVE: Evaluate the current state of knowledge regarding late-onset (i.e. age-of-onset $\geq 12$ years) ADHD. MATERIAL AND METHODS: Systematic literature review using PubMed (MEDLINE) and SCOPUS databases. RESULTS: We found six studies reporting data offering some support for the existence of late-onset ADHD: five from the PubMed search and one from the non-overlapping articles in the SCOPUS search. DISCUSSION: Despite the small number of studies, the differences in methodology among them and the presence of limitations in all of them, data regarding clinical aspects offer some support for the content validity of late-onset ADHD diagnosis in adults. CONCLUSIONS: Although many controversies still exist and studies supporting its construct validity are needed, late-onset ADHD may be a valid diagnosis in adults. Thus, clinicians should consider diagnosing and treating late-onset ADHD in adults, instead of just neglecting this possibility because of the age-of-onset criterion.
\end{abstract}

Keywords: Attention deficit disorder with hyperactivity; Lateonset; Adult; Diagnosis Validity.
RESUMO: INTRODUÇÃO: O paradigma atual do Transtorno de Déficit de Atenção e Hiperatividade (TDAH) o entende como um transtorno do neurodesenvolvimento de início na infância, que pode persistir na vida adulta. Entretanto, foi levantada a hipótese de uma síndrome de TDAH de início tardio (idade de início $\geq 12$ anos). OBJETIVO: Avaliar o atual estado do conhecimento em relação ao TDAH de início tardio. MATERIAL E MÉTODOS: Revisão sistemática da literatura usando as bases de dados PubMed (MEDLINE) e SCOPUS. RESULTADOS: Nós encontramos seis estudos que relatam dados corroborando a existência do TDAH de início tardio: cinco da busca no PubMed e um dos artigos sem sobreposição da busca no SCOPUS. DISCUSSÃO: Apesar do pequeno número de estudos, das diferenças de metodologia entre eles e da presença de limitações em todos eles, os dados relativos a aspectos clínicos oferecem alguma sustentação para a validade de conteúdo do diagnóstico de TDAH em adultos de início tardio. CONCLUSÕES: Embora muitas controvérsias ainda existam e estudos confirmando sua validade de construto são necessários, TDAH de início tardio pode ser um diagnóstico válido em adultos. Portanto, clínicos devem considerar o diagnóstico e tratamento de TDAH em adultos de início tardio ao invés de simplesmente negligencia-lo devido ao critério de idade de início.

Descritores: Transtorno do déficit de atenção com hiperatividade; Validade dos testes; Adolescente; Adulto; Adulto jovem.

Artigo desenvolvido na Disciplina Optativa Abordagem Prática da Escrita Científica da Revista de Medicina - DCFMUSP (2016-2017).

1. Faculdade de Medicina FMUSP, Universidade de São Paulo, São Pulo, BR. Acadêmico de Medicina da FMUSP. Email: mauro. xavier.neto@usp.br, https://orcid.org/0000-0003-0112-258X.

2. Faculdade de Medicina FMUSP, Universidade de São Paulo, São Pulo, BR. Acadêmica de Medicina da FMUSP. Email: sofia. amaral@fm.usp.br, https://orcid.org/0000-0003-2174-2559.

3. Faculdade de Medicina FMUSP, Universidade de São Paulo, São Pulo, BR. Acadêmica de Medicina da FMUSP. Email: luiza. campos@fm.usp.br, https://orcid.org/0000-0003-1745-6103.

4. Faculdade de Medicina FMUSP, Universidade de São Paulo, São Pulo, BR. Orientador. Email: fraguasr@gmail.com. https://orcid. org/0000-0002-3052-066X

Endereço para correspondência: Mauro Xavier Neto. Rua Capote Valente, 929, ap 53-B. Pinheiros, São Paulo, SP. CEP: $05409-002$. 


\section{INTRODUCTION}

$\mathrm{T}$ he current Attention Deficit Hyperactivity Disorder (ADHD) paradigm understands it as a childhood-onset neurodevelopmental disorder that can persist into adult life. The disorder is characterized by inappropriate developmentally and impairing inattention, motor hyperactivity, and impulsivity ${ }^{1}$. ADHD is a diagnostic category in the American Psychiatric Association's Diagnostic and Statistical Manual of Mental Disorders 4th edition (DSM-IV, 1994) ${ }^{2}$. DSM-IV's diagnostic criteria required symptoms onset causing impairment before age 7 years. In the most recent version (DSM-5, 2013) ${ }^{3}$, there are longer symptom descriptions and the onset needs to be prior to 12 years. In addition, DSM- 5 criteria do not require the presence of a noticeable impairment before the age 12 years when the diagnosis is made later in life. This broader diagnostic criteria has been shown to not over-include individuals without impairment ${ }^{4}$. In a 2015 editorial, Xavier-Castellanos ${ }^{5}$, based on the study of Moffitt et al. ${ }^{6}$, conceived late-onset ADHD as a distinct entity, in which symptoms onset occurs after age 12 years. This concept challenges the hegemonic definition of ADHD as an essentially neurodevelopmental disorder, and opens an intriguing line of investigation of a novel condition, including a possible distinct etiopathology. If confirmed, in face of an adult with ADHD symptoms, one could have an early-onset or a late-onset condition. Diagnosing late-onset adult ADHD represents a perspective of potential effective treatment for many people that currently are not properly assisted. Thereby, the goal of this review is to investigate current evidence supporting the validity of late-onset ADHD (i.e. symptom onset after age 12 years) diagnosis.

\section{MATERIAL AND METHODS}

To evaluate the current state of knowledge regarding late-onset adult ADHD, we conducted a systematic literature review. To be included, manuscripts should have original data, had assessed ADHD in adults with symptom onset at age 12 years or older, be written in English or Portuguese, and had been published until April 2017. We initiated our search in the PubMed (MEDLINE) database. Considering the topic is very recent, we used both Medical Subject Headings (Mesh) term and keywords to search articles: ("attention deficit disorder" OR "attention deficit hyperactivity disorder" OR “ADHD” OR “Attention Deficit Disorder with Hyperactivity"[Mesh]) AND ("late onset" OR "later onset" OR “age at onset” OR "age of onset" OR "adult onset" OR "adulthood onset" OR “adolescent onset" OR "adolescence onset") AND adult. It yielded 311 results on total, 294 in English or Portuguese. We also replicated the same search on SCOPUS database. As SCOPUS does not work with Mesh terms, we used simply keywords, yielding 490 results, 459 in English or Portuguese.

From the PubMed search, we initially included nine articles based on tittle and abstract, then we excluded four articles after reading full text. When comparing the results from both databases, we found an overlap of 189 articles. From the 270 non-overlapping articles of SCOPUS search, two articles were initially included based on tittle and abstract, one of them was excluded after reading the full text. We ended up with 6 manuscripts (i.e. 5 from PubMed +1 non-overlapped from SCOPUS). Figure 1 shows the review flowchart.

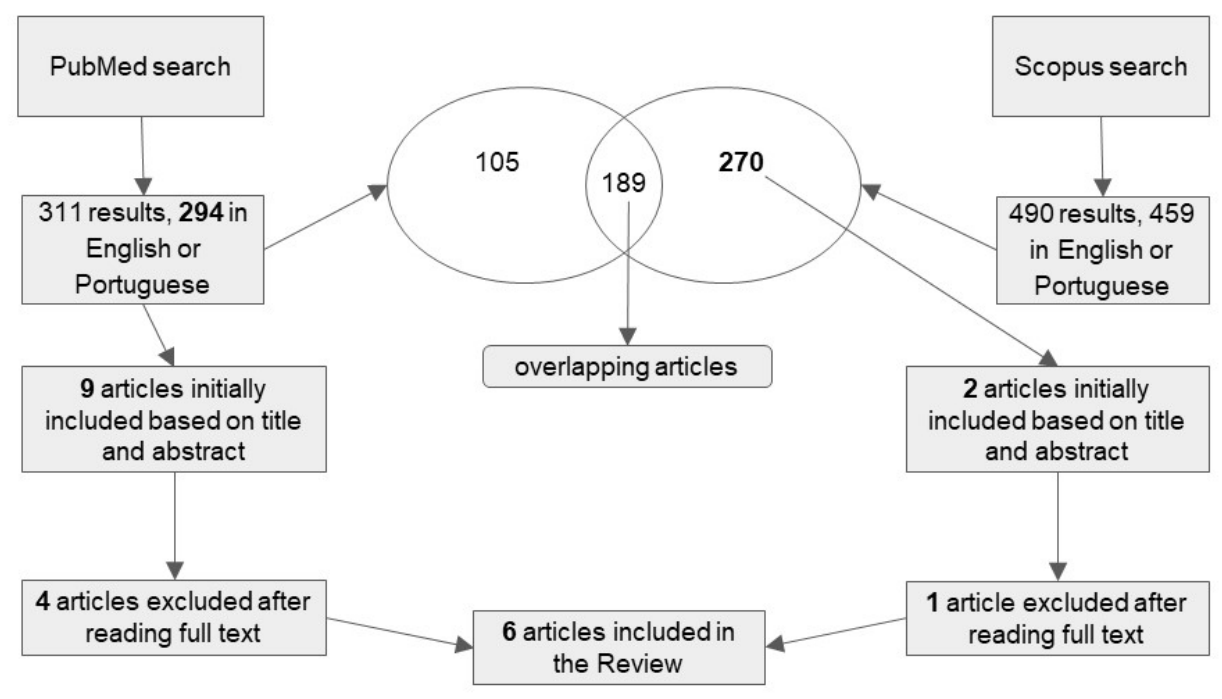

Figure 1. Systematic literature review flowchart 


\section{RESULTS}

We found six studies reporting data supporting the existence of a clinical picture in adults fulfilling the criteria for the diagnosis of ADHD according to the DSM-5, except age of onset. To better visualize the data, we created two tables. Table 1 shows general characteristics of the studies, including study design, sample characteristics, early/lateonset ADHD definition and prevalence for each study (both general and within adult ADHD, when possible). Table 2 shows clinical and sociodemographic aspects pertaining to late- and early-onset adult ADHD among studies with such information available.

\section{Demographics}

Gender and age were the most studied features in the selected articles, assessed in five from the six selected articles. Four studies showed comparison data. Although assessed in most studies, these features were not always treated and presented in the same way. Therefore, attention in interpreting the results is important. For example, Chandra et al. ${ }^{7}$ did not observe any statistical difference in age and gender between early-onset ADHD, late-onset
ADHD and controls. In another study, Caye et al. ${ }^{8}$ compared the groups in a different way: there was a group of people diagnosed with ADHD in childhood (early-onset ADHD) and a group of those diagnosed with ADHD as young adults (late-onset ADHD). They compare each category to controls, and found that early-onset ADHD individuals had significant male preponderance, whereas the lateonset ADHD group had a female preponderance. A similar approach was made by Moffitt et al. ${ }^{6}$ : early-onset ADHD individuals were predominantly male, and late-onset ADHD individuals did not show any significant difference in gender distribution when compared to controls. However, we cannot affirm that there is a significant difference on gender distribution between adults with early and late-onset ADHD, since that comparison was not made. Agnew-Blais et al. ${ }^{9}$ make the comparisons differently: the late-onset ADHD group is compared directly with the early-onset ADHD group: among 166 individuals with adult ADHD, $112(67.5 \%)$ had late-onset ADHD. Late-onset individuals were more likely to be female. There is a last article that approaches the gender distribution issue: Vitola et al. ${ }^{10}$ mention that in the late-onset group, the expected male preponderance of ADHD is not maintained, but it does not provide the comparison data.

Table 1. Studies reporting late-onset adult ADHD: studies' characteristics and prevalence of ADHD

\begin{tabular}{|c|c|c|c|c|c|}
\hline \multirow{2}{*}{ Study } & \multirow{2}{*}{$\begin{array}{c}\text { Study design and general sample } \\
\text { characteristics }\end{array}$} & \multicolumn{2}{|c|}{ Early-onset adult ADHD } & \multicolumn{2}{|c|}{ Late-onset adult ADHD } \\
\hline & & definition & prevalence - N (\%) & definition & prevalence - N (\%) \\
\hline $\begin{array}{l}\text { Kennedy } \\
\text { et al., } 2016\end{array}$ & $\begin{array}{l}\text { Prospective cohort study. Individuals } \\
\text { adopted as young children by UK } \\
\text { families. } 165 \text { Romanian adoptees } \\
\text { and } 52 \text { comparison UK adoptees. } \\
\text { By the young adult follow-up (ages } \\
22-25 \text { years), this number dropped } \\
\text { to } 164 \text {. Data on ADHD symptoms } \\
\text { were available for } 143 \text { individuals } \\
\text { in young adulthood. } 126 \text { individuals } \\
\text { had data on ADHD at all entries } \\
\text { (ages } 6,11,15 \text { and } 22-25 \text { ). }\end{array}$ & $\begin{array}{l}\text { Young adults (22- } \\
25 \text { years) that meet } \\
\text { DSM-5 criteria for } \\
\text { ADHD, including } \\
\text { age at onset, who } \\
\text { also met the criteria } \\
\text { when } 15 \text { years of age } \\
\text { or younger (parent } \\
\text { report). }\end{array}$ & $\begin{array}{l}\text { General: } 9(7.14 \%) \text {. } \\
\text { Within adult } \\
\text { ADHD: } 50 \%\end{array}$ & $\begin{array}{l}\text { Young adults ( } 22-25 \\
\text { years) that meet DSM- } \\
5 \text { criteria for ADHD, } \\
\text { except age at onset; } \\
\text { criteria for ADHD was } \\
\text { fulfilled only after } 15 \\
\text { years of age (parent } \\
\text { report). }\end{array}$ & $\begin{array}{l}\text { General: } 9(7.14 \%) \text {. } \\
\text { Within adult ADHD: } \\
50 \% \text {. }\end{array}$ \\
\hline $\begin{array}{l}\text { Caye et } \\
\text { al., } 2016\end{array}$ & $\begin{array}{l}\text { Prospective cohort study. Individuals } \\
\text { enrolled in this study were } \\
\text { participants in the } 1993 \text { Pelotas } \\
\text { Birth Cohort. All children born in } \\
1993 \text { in the city of Pelotas, Brazil } \\
\text { ( } 5249 \text { individuals), were assessed at } \\
\text { multiple time points and followed } \\
\text { up until } 18 \text { to } 19 \text { years of age, with } \\
\text { a retention rate of } 81.3 \% \text {. } 4023 \\
\text { individuals had data on ADHD } \\
\text { at both } 11 \text { years and } 18-19 \text { years } \\
\text { assessments ( } 4039 \text { observations at } \\
\text { young adult assessment minus } 16 \\
\text { missing observations on childhood } \\
\text { assessment). }\end{array}$ & $\begin{array}{l}\text { Young adults (18- } \\
19 \text { years) that meet } \\
\text { DSM-5 criteria } \\
\text { for ADHD (self- } \\
\text { report), including } \\
\text { age at onset, who } \\
\text { also scored } 8 \text { or } \\
\text { more points on } \\
\text { the Strengths } \\
\text { and Difficulties } \\
\text { Questionnaire } \\
\text { hyperactivity scale } \\
\text { when } 11 \text { years old, } \\
\text { associated with at } \\
\text { least } 1 \text { point in the } \\
\text { impact supplement } \\
\text { (parent report). }\end{array}$ & $\begin{array}{l}\text { General: } 60 \\
(1.49 \%) . \text { Within } \\
\text { adult ADHD: } \\
12.6 \% \text {. }\end{array}$ & $\begin{array}{l}\text { Young adults (18- } \\
19 \text { years) that meet } \\
\text { DSM-5 criteria for } \\
\text { ADHD (self-report), } \\
\text { except age at onset, } \\
\text { who scored less than } 8 \\
\text { points on the Strengths } \\
\text { and Difficulties } \\
\text { Questionnaire } \\
\text { hyperactivity } \\
\text { scale when } 11 \text { years old } \\
\text { and/or scored no point in } \\
\text { the impact supplement } \\
\text { (parent report). }\end{array}$ & $\begin{array}{l}\text { General: } 416 \\
(10.34 \%) \text {. Within } \\
\text { adult ADHD: } 87.4 \% \text {. }\end{array}$ \\
\hline
\end{tabular}


Xavier M, et al. Is late-onset Attention Deficit Hyperactivity Disorder (ADHD) a valid diagnosis in adults?

Table 1. Studies reporting late-onset adult ADHD: studies' characteristics and prevalence of ADHD

continuation

\begin{tabular}{|c|c|c|c|c|c|}
\hline \multirow{2}{*}{ Study } & \multirow{2}{*}{$\begin{array}{c}\text { Study design and general sample } \\
\text { characteristics }\end{array}$} & \multicolumn{2}{|c|}{ Early-onset adult ADHD } & \multicolumn{2}{|c|}{ Late-onset adult ADHD } \\
\hline & & definition & prevalence - N (\%) & definition & prevalence - N (\%) \\
\hline $\begin{array}{l}\text { Vitola et } \\
\text { al., } 2017\end{array}$ & $\begin{array}{l}\text { Cross-sectional study assessing } \\
\text { 30-year-old adults from the } 1982 \\
\text { Pelotas Birth Cohort Study. From } \\
\text { all live born infants from the year } \\
1982(\mathrm{n}=5914) \text { in Pelotas, } 3701 \\
\text { were reassessed in } 2012 . \text { These } \\
3701 \text { individuals plus the } 325 \text { who } \\
\text { died before } 2012 \text { represent a } 68.1 \% \\
\text { retention rate ( } \mathrm{n}=4026) \text {. The study } \\
\text { was carried out with the } 3574 \\
\text { subjects screened for ADHD, } 3369 \\
(94.26 \%) \text { of those with complete } \\
\text { data. }\end{array}$ & $\begin{array}{l}30 \text {-year-old adults } \\
\text { who met full DSM-5 } \\
\text { criteria, including } \\
\text { age of onset (before } \\
12 \text { years of age) (self } \\
\text { report). }\end{array}$ & $\begin{array}{l}\text { General: } 2.1 \% \\
\text { considering subjects } \\
\text { with complete data } \\
(\mathrm{n}=3369), 2.4 \% \\
\text { when imputation } \\
\text { for missing data } \\
\text { was used ( }=3574) \text {. } \\
\text { Within adult } \\
\text { ADHD: } 36.2 \% \text {. }\end{array}$ & $\begin{array}{l}30 \text {-year-old adults who } \\
\text { met DSM- } 5 \text { criteria, } \\
\text { ignoring the age of } \\
\text { onset criterion (before } \\
12 \text { years of age) (self } \\
\text { report). }\end{array}$ & $\begin{array}{l}\text { General: } 3.7 \% \\
\text { considering subjects } \\
\text { with complete data } \\
\text { ( } \mathrm{n}=3369 \text { ). Within } \\
\text { adult ADHD: } 63.8 \% \text {. }\end{array}$ \\
\hline $\begin{array}{l}\text { Agnew- } \\
\text { Blais, } \\
2016\end{array}$ & $\begin{array}{l}\text { Nationally representative birth } \\
\text { cohort of } 2232 \text { twins born in } \\
\text { England and Wales from January } 1 \text {, } \\
\text { 1994, to December 4, 1995. } 2040 \\
\text { were included in this analysis. } \\
\text { Data analysis was conducted from } \\
\text { February } 19 \text { to September } 10,2015 . \\
\text { Attention-deficit/hyperactivity } \\
\text { disorder according to DSM-IV } \\
\text { diagnostic criteria in childhood and } \\
\text { DSM-5 diagnostic criteria in young } \\
\text { adulthood. }\end{array}$ & $\begin{array}{l}\text { Persistent ADHD: } \\
\text { met full diagnostic } \\
\text { criteria (DSM-5) both } \\
\text { in childhood (up to } \\
\text { age } 12 \text { ) and at age } 18 .\end{array}$ & $\begin{array}{l}\text { General: } 2.4 \% \text {. } \\
\text { Within adult } \\
\text { ADHD: } 32.5 \% \text {. }\end{array}$ & $\begin{array}{l}\text { Did not meet criteria } \\
\text { in childhood (up } \\
\text { to age } 12 \text { ) but had } \\
\text { elevated symptoms and } \\
\text { impairment at age } 18\end{array}$ & $\begin{array}{l}\text { General: } 5.01 \% \text {. } \\
\text { Within adult ADHD: } \\
67.5 \% \text {. }\end{array}$ \\
\hline $\begin{array}{l}\text { Chandra, } \\
2016\end{array}$ & $\begin{array}{l}\text { Cross-sectional retrospective study } \\
\text { of ADHD ( } 182 \text { early-onset and } 17 \\
\text { late-onset) and non-ADHD ( } 117) \\
\text { probands, ages 18-55, recruited } \\
\text { through referrals from Massachusetts } \\
\text { General Hospital (MGH) (ADHD } \\
\text { probands) and advertisements in the } \\
\text { Boston area (ADHD and non-ADHD } \\
\text { probands). The probands and all } \\
\text { their available close relatives were } \\
\text { ascertained and assessed. }\end{array}$ & $\begin{array}{l}\text { Adults } 18-55 \text { years } \\
\text { who met all DSM- } 5 \\
\text { criteria. }\end{array}$ & $\begin{array}{l}182(91.5 \%) \text { in } 199 \\
\text { ADHD adults. }\end{array}$ & $\begin{array}{l}\text { Adults } 18-55 \text { years who } \\
\text { met all DSM- } 5 \text { criteria } \\
\text { except age at onset. }\end{array}$ & $\begin{array}{l}17(8.5 \%) \text { in } 199 \\
\text { ADHD adults. }\end{array}$ \\
\hline $\begin{array}{l}\text { Moffitt et } \\
\text { al., } 2015\end{array}$ & $\begin{array}{l}\text { Participants belonged to a } \\
\text { representative birth cohort of } \\
1,037 \text { individuals born in Dunedin, } \\
\text { New Zealand, in } 1972 \text { and } 1973 \\
\text { and followed to age } 38 \text {, with } \\
95 \% \text { retention. Data sources were } \\
\text { participants, parents, teachers, } \\
\text { informants, neuro-psychological test } \\
\text { results, and administrative records. } \\
\text { Adult ADHD diagnoses used DSM- } \\
5 \text { criteria, apart from onset age and } \\
\text { cross-setting corroboration, which } \\
\text { were study outcome measures. }\end{array}$ & $\begin{array}{l}\text { Children diagnosed } \\
\text { with ADHD at } \\
\text { ages } 11,13 \text {, and } 15 \\
\text { between } 1984 \text { and } \\
\text { 1988. Symptoms } \\
\text { were ascertained } \\
\text { using the Diagnostic } \\
\text { Interview Schedule } \\
\text { for Children-Child } \\
\text { Version at ages } 11 \\
\text { and } 13 \text { by a child } \\
\text { psychiatrist and at } \\
\text { age } 15 \text { by trained } \\
\text { interviewers. Then, } \\
\text { at the age of } 38 \text { they } \\
\text { were diagnosed } \\
\text { again, following the } \\
\text { DSM-5. }\end{array}$ & $\begin{array}{l}\text { General: } 0.3 \% \text {. } \\
\text { Within adult } \\
\text { ADHD: } 10 \%\end{array}$ & $\begin{array}{l}\text { Adult ADHD Diagnosis: } \\
\text { symptoms were } \\
\text { ascertained when } \\
\text { participants were age } \\
38 \text { through structured } \\
\text { diagnostic interviews } \\
\text { by trained interviewer. } \\
\text { Research diagnoses } \\
\text { followed DSM-5 } \\
\text { except age at onset. In } \\
\text { further analysis, this } \\
\text { group was merged } \\
\text { with the early-onset } \\
\text { group, being referred } \\
\text { to as "Adult ADHD } \\
\text { group" (in comparison } \\
\text { to Childhood ADHD - } \\
\text { adults with ADHD also } \\
\text { diagnosed with ADHD } \\
\text { as children). }\end{array}$ & $\begin{array}{l}\text { General: } 2.79 \% \text {. } \\
\text { Within adult ADHD: } \\
90 \% \text {. }\end{array}$ \\
\hline
\end{tabular}


Table 2. Clinical and sociodemographic aspects: late- and early-onset adult ADHD

\begin{tabular}{|c|c|c|}
\hline & Study & Result \\
\hline \multicolumn{3}{|l|}{ Clinical presentation } \\
\hline Inattention & Agnew-Blais, 2016 & No difference between early- and late-onset groups. \\
\hline \multirow{2}{*}{$\begin{array}{l}\text { General psychiatric } \\
\text { severity }\end{array}$} & Kennedy et al., 2016 & $\begin{array}{l}\text { Late-onset group had lower scores on the CAPA (Child and Adolescent Psychiatric } \\
\text { Assessment); early-onset group (persisters) had more complex and severe presentation. }\end{array}$ \\
\hline & Chandra 2016 & Late-onset group scored lower on lifetime reports of hyperactive and inattentive symptoms. \\
\hline Anxiety severity & Kennedy et al., 2016 & No difference on the Conners Comprehensive Behaviour Rating Scales (CBRS). \\
\hline \multicolumn{3}{|l|}{ Comorbidity } \\
\hline & Agnew-Blais, 2016 & No diference. \\
\hline & Chandra, 2016 & $\begin{array}{l}\text { No difference in prevalence between early vs late-onset ADHD; although both groups show } \\
\text { greater prevalence than controls (non-ADHD). }\end{array}$ \\
\hline & Kennedy et al., 2016 & $\begin{array}{l}\text { Early-onset group: higher levels of anxiety, depression, callous and unemotional traits, } \\
\text { disinhibited social engagement and lower IQ (analysis lacked statistical power). }\end{array}$ \\
\hline & Moffitt, 2015 & $\begin{array}{l}\text { Early-onset ADHD group: elevated rates of conduct disorder, depression and anxiety as } \\
\text { children (more prominent than among late-onset ADHD group). } \\
\text { No difference in mania, depression or anxiety disorders as adults between the two groups. } \\
\text { Late-onset ADHD group: elevated rates of dependence on alcohol, cannabis or other drugs, } \\
\text { tobacco dependence, mental health professional seeking and medication treatment for a } \\
\text { problem other than ADHD. }\end{array}$ \\
\hline \multicolumn{3}{|l|}{ Familial risk } \\
\hline & Chandra, 2015 & $\begin{array}{l}\text { 1) Risk for early-onset ADHD among relatives of probands with early-onset ADHD and } \\
\text { late-onset ADHD did not differ, but were significantly higher than the risk to relatives of } \\
\text { controls. } \\
\text { 2) Risk for late-onset ADHD between relatives of probands having early-onset ADHD was } \\
\text { significantly higher than the relatives of controls. }\end{array}$ \\
\hline & Moffitt, 2015 & $\begin{array}{l}\text { A genome-wide polygenic risk score derived from genome-wide association studies } \\
\text { (GWAS) of childhood ADHD was significantly elevated in the childhood ADHD group, but } \\
\text { not in the adult ADHD group. }\end{array}$ \\
\hline \multicolumn{3}{|l|}{ Associated features } \\
\hline Externalizing problems & Agnew-Blais, 2016 & Late-onset ADHD showed fewer externalizing problems. \\
\hline \multirow{2}{*}{ Home or friends } & Agnew-Blais, 2016 & No diference. \\
\hline & Chandra 2016 & Late-onset ADHD showed worse ratings in social/leisure functioning. \\
\hline \multirow[b]{3}{*}{ School or work } & Agnew-Blais, 2016 & No difference at school or work. \\
\hline & Chandra, 2016 & No difference at school. Late-onset ADHD showed worse ratings on work functioning. \\
\hline & Moffitt, 2015 & $\begin{array}{l}\text { Early-onset ADHD group: deficits in reading achievement, trail making test and verbal } \\
\text { learning-delayed recall. } \\
\text { Late-onset ADHD group: no significant cognitive deficits as children apart from mild } \\
\text { reading delay. }\end{array}$ \\
\hline \multirow[b]{2}{*}{ Education/income } & Agnew-Blais, 2016 & $\begin{array}{l}\text { Late-onset ADHD individuals had higher age- } 18 \text { IQ compared with the persistent ADHD } \\
\text { group, but the two groups did not differ significantly on life satisfaction, job preparedness, } \\
\text { and rates of being engaged in formal education. }\end{array}$ \\
\hline & Moffitt, 2015 & $\begin{array}{l}\text { Relative to the comparison group, a significantly smaller percentage of the early-onset } \\
\text { ADHD group completed a university degree, and they reported significantly lower income. } \\
\text { Although the late-onset ADHD group did not differ significantly from the comparison group } \\
\text { on university education or income, they reported significantly fewer saving behaviors and } \\
\text { more troubles with debt and cash flow. Administrative records revealed that the late-onset } \\
\text { ADHD group also had significantly lower credit ratings, longer duration of social welfare } \\
\text { benefit receipt, and more injury-related insurance claims than the comparison group. }\end{array}$ \\
\hline \multirow{3}{*}{ Psychosocial } & Agnew-Blais, 2016 & No difference on life satisfaction. \\
\hline & Chandra, 2016 & $\begin{array}{l}\text { Late-onset showed worse ratings on well-being, life satisfaction and functioning in daily } \\
\text { life. }\end{array}$ \\
\hline & Moffitt, 2015 & $\begin{array}{l}\text { The impairment history was worse among those with late-onset ADHD. They reported } \\
\text { markedly elevated impairment as a result of ADHD-associated problems, felt less satisfied } \\
\text { with their lives, and reported problems stemming from being disorganized, underachieving, } \\
\text { exhausting or draining to others, having risky driving and accidents from overdoing it. }\end{array}$ \\
\hline
\end{tabular}




\section{Clinical presentation and comorbidity}

We evaluated clinical features concerning comorbidity levels and clinical presentation, including prevalence of the inattention component, general psychiatric severity and anxiety severity. Pertaining to the clinical presentation per se, most studies have found increased psychopathological severity in early compared to lateonset ADHD. Compared to early-onset adult ADHD, two studies found lower scores for the late-onset adult ADHD group in regard to general psychiatric severity - one on the CAPA (Child and Adolescent Psychiatric Assessment) ${ }^{11}$ and another on lifetime reports of hyperactive and inattentive symptoms ${ }^{7}$. One study found a more complex and severe presentation on early-onset adult ADHD cases, but no difference between the two groups on anxiety severity ${ }^{11}$. Another study found no difference between early and lateonset groups regarding the inattention component ${ }^{9}$.

Late-onset adult ADHD was reported to have no difference in prevalence of comorbidities in relation to early-onset adult ADHD by two studies ${ }^{7,9}$, while in comparison with non-ADHD individuals, greater prevalence of comorbidities was found in both groups? During childhood, those with early-onset ADHD who did not present ADHD during adulthood had higher rates of conduct disorder, depression and anxiety compared to those with late-onset $\mathrm{ADHD}^{6}$. However, it should be noted that $90 \%$ of adult ADHD were late-onset individuals. Also, adults that had ADHD during childhood but were free from ADHD diagnosis during adulthood had a history of conduct disorder, but this association was more prominent among early-onset ADHD cases. There was no difference in mania, depression or anxiety disorders during adulthood between the two groups. The late-onset ADHD group had, in comparison to the early-onset ADHD group, higher rates of dependence on alcohol, cannabis or other drugs, tobacco dependence, mental health professional seeking and medication treatment for a problem other than ADHD. It is important to note that only $55 \%$ of adults with ADHD had no other concurrent disorders. A study also found that the early-onset ADHD group had higher levels of anxiety, depression, callous and unemotional traits, disinhibited social engagement and lower IQ when compared to controls, but no difference in these parameters when compared to late-onset $\mathrm{ADHD}^{11}$.

\section{Familial risk}

Two studies have analyzed the hereditary aspect of ADHD, however using different methods. Moffitt et al. ${ }^{6}$ used Genome Wide Associations (GWAS) and found out that the genome-wide polygenic risk score was elevated in early-onset ADHD individuals, but not in the lateonset ADHD group. Meanwhile, Chandra et al. ${ }^{7}$ made a comparison on the prevalence of ADHD in relatives of the three groups: controls, late-onset ADHD and early-onset ADHD. They found out that the risk for early-onset ADHD among relatives of probands with early-onset ADHD and late-onset ADHD did not differ, but were significantly higher than the risk of controls. In addition, the risk for late-onset ADHD between relatives of probands having early-onset ADHD was significantly higher than the relatives of controls.

\section{Associated features}

Concerning features associated to the ADHD diagnosis, we found and compared data on externalizing problems and ADHD-related impairment in school achievement, work performance, family and friend relationship, and education/income.

\section{Externalizing problems}

One study found fewer externalizing problems in childhood in the late-onset ADHD group in comparison to the early-onset ADHD group, but at age 18 the two groups did not differ significantly on life satisfaction, job preparedness, and rates of being engaged in formal education?.

\section{School or work}

Three of the analyzed studies had data pertaining to ADHD interference in school or work. One found no significant difference in school or work impairment between early and late-onset $\mathrm{ADHD}^{9}$, while the two others found disparities.

Chandra et al. ${ }^{7}$ found similar intelligence when comparing early versus late-onset ADHD individuals, however late-onset ADHD subjects showed worse ratings on work functioning.

Moffitt et al. ${ }^{6}$ found that, at childhood, the earlyonset ADHD group had deficits in reading achievement, trail making test and verbal learning-delayed recall test, while the late-onset ADHD group had no significant cognitive deficits as children apart from a mild reading delay.

\section{Education and income}

Two studies assessed the difference on level of formal education and occupational status. Both studies compared late-onset versus early-onset adult ADHD groups, and both had control groups of people without ADHD. According to Agnew-Blais et al. ${ }^{9}$, both ADHD groups did not differ from controls in terms of readiness for work and formal education level. On the other hand, Moffitt et al. found difference between the early-onset ADHD group and the control group: early-onset ADHD individuals had a smaller percentage of individuals with university degree, besides reporting smaller income. The late-onset 
ADHD group did not show difference in education and income when comparing to controls, but showed higher problems in personal finance administration ${ }^{6}$.

\section{Psychosocial}

Three studies have analyzed the psychosocial sphere, focusing primarily in the life satisfaction level in adult life: Agnew-Blais et al. ${ }^{9}$ did not observe any significant difference in life satisfaction between the early and late-onset adult ADHD groups. Chandra et al. ${ }^{7}$ demonstrated that the late-onset ADHD group scored significantly worse on sense of well-being, overall life satisfaction, and functioning in daily adult life compared with the full ADHD group. Moffitt et al. ${ }^{6}$ reported inferior levels of well-being and life satisfaction in the late-onset adult ADHD group.

\section{DISCUSSION}

\section{Diagnostic validity in Psychiatry}

Validity of psychiatric diagnosis is an ongoing discussion. In a literature review of the concept of validity in psychiatry, Aboraya ${ }^{12}$ highlights four main types of validity: content, criterion, construct and procedural. Content validity refers to the degree to which an empirical measurement reflects a specific domain of content (e. g. delusions and hallucinations as symptoms of schizophrenia). Criterion validity is an assessment of something external to the measurement instrument itself, which helps to corroborate the diagnosis (e. g. glucose tolerance test for diabetes). Construct validity can refer to the extent to which a particular measure relates to other measures consistent with theoretically derived hypotheses (e.g. young age of onset and positive family history are part of the construct of the diagnosis of schizophrenia), which consists of a convergent validity ${ }^{12}$. On the contrary, construct validity may consist of measures that vary independently of a particular one, indicating discriminant validity ${ }^{13}$. Procedural validity refers to the adequacy of a new diagnostic procedure in replacing or simulating some existent procedure (e. g. using a structured interview to replace an open-ended interview by a clinician $)^{12}$. Jablensky ${ }^{14}$ expand this discussion by pointing that there is little evidence that the majority of recognized mental disorders are valid, but that these classifications can be useful if they provide non-trivial information about prognosis and likely treatment outcomes, and/or testable propositions about biological and social correlates. He understands diagnostic categories as constructs that provide a useful framework for organizing clinical experience, generating predictions, and making treatment decisions.

Conceptual and methodological issues in the diagnosis of $A D H D$ in adults
The validity of the ADHD diagnosis faces not only the above mentioned problems. The diagnosis of ADHD in adults, requiring an age of onset before 12 years, has an additional concern regarding recall bias. The validity of retrospective recall in ADHD diagnosis in adults, using different report sources (self, parents, teachers), has been the subject of some studies ${ }^{15,16}$. The results are heterogeneous, but point that its diagnosis has a moderate stability and limited internal consistency.

The challenge of the age-of-onset criterion had been posed previously. When the age of onset cutoff was 7 years, studies concluded that late-onset adult ADHD (i.e. onset after age 7) was valid and that DSM-IV`s age-of-onset criterion was too stringent ${ }^{17,18}$. The current DSM-5 requires an age-of-onset before 12 years. In a validation study of the new age-of-onset criterion, Lin et al. ${ }^{4}$ concludes that their data support decreased quality of life and increased functional impairment in adult ADHD, regardless of the age of onset being before 7 or 12 years, implying that the new DSM-5 criteria do not over-include individuals without impairment .

The increase in the age-of-onset cut-off in DSM-5 was beneficial, but many conceptual and methodological issues remain. In a review of lifespan studies of ADHD, Caye et al. ${ }^{19}$ point to the existence of a late-onset ADHD trajectory. However, caution about their findings have been claimed. First, the late-onset cases may be due to false negative recall of childhood ADHD symptoms. Questions have been raised regarding the reliability of report sources, including the problem of recall bias mentioned previously. Sibley et al. ${ }^{20}$ made a review on the subject and found that methods for diagnosing ADHD in adulthood varied widely with respect to source of information, diagnostic instruments, diagnostic symptom threshold and whether impairment was required for diagnosis or not. Those differences influenced the estimated persistence of childhood ADHD into adulthood. However, these questionings have already been raised for changing the cutoff from age of 7 to 12 years, and the conclusions pointed towards increasing the cutoff. Thus, although these questions deserves consideration, they are not an evidence that late onset ADHD diagnosis is prohibitive.

\section{Is late-onset $A D H D$ a valid diagnosis?}

With these questions in mind, we can better understand and interpret the information in Table 1. Moffitt et al. ${ }^{6}$ were the first to assess the prevalence of late-onset ADHD in the current paradigm (after 12 years-old); after them, two other studies used the same referential. The reported late-onset adult ADHD prevalence in general population was $2.79 \%, 10.34 \%$ and $5.01 \%$ respectively in the study of Moffitt et al. ${ }^{6}$, Caye et al. ${ }^{8}$ and Agnew-Blais et al. ${ }^{9}$. Although some difference might be noted, these results 
Xavier M, et al. Is late-onset Attention Deficit Hyperactivity Disorder (ADHD) a valid diagnosis in adults?

highlight the relevance of considering the diagnosis of late-onset adult ADHD. Additionally, among adult ADHD cases, most were represented by late-onset individuals, $90 \%, 87.4 \%$ and $67.5 \%$ respectively in the study of Moffitt et al. ${ }^{6}$, Caye et al. ${ }^{8}$ and Agnew-Blais et al. ${ }^{9}$, supporting the relevance of considering the diagnosis not only for those with onset before age of 12 years. Kennedy et al. ${ }^{11}$ did not used 12 years as the cutoff for late-onset: when applying the definition of late-onset ADHD for those with onset after 15 years, we extract a prevalence of $7.14 \%$ in general population, representing 50\% of the adult ADHD individuals. Although Chandra et al. ${ }^{7}$ reported a prevalence of only $8.5 \%$ of late-onset ADHD among ADHD adults, they used a convenience sample, which precludes the appreciation of such finding. The most recent study, from Vitola et al. ${ }^{10}$, found a prevalence of $3.7 \%$ for late-onset adult ADHD in general population, and $63.79 \%$ within those with adult ADHD; which is close to the lower limit range of the first three studies mentioned above. Despite the small number of studies, the differences in methodology among them and the presence of limitations in all of them, the relative constancy of these data regarding prevalence offers some support for the content validity of late-onset adult ADHD diagnosis, which is, the late onset specification maintain the consistency of diagnosing ADHD by its symptoms domains.

Besides prevalence data, studies have shown that adults with late-onset ADHD, compared to normal controls, have psychosocial impairment, including poor credit scores, cash flow problems, poor savings behavior, more government support, higher numbers of insurance claims ${ }^{6}$, higher rates of comorbidity ${ }^{6,7}$, higher levels of anxiety, depression, callous and unemotional traits, disinhibited social engagement and lower $\mathrm{IQ}^{11}$. Additionally, the risk for late-onset ADHD between relatives of probands having early-onset ADHD was significantly higher than the relatives of controls ${ }^{7}$. There is some disagreement among studies, and studies with formal validity analysis are missing. However, the association of late-onset ADHD with the above-mentioned parameters, offers support to the underlying construct of late-onset ADHD as an entity. Such negative psychosocial association and possible familial genetic factor, differentiating late-onset ADHD from normal controls, support a discriminant construct validity.

\section{Is late-onset ADHD syndrome different from early-onset} ADHD?

Current discussions focus not only on the existence of late-onset ADHD, but also in whether it is a syndrome different from early-onset ADHD. Moffitt et al. ${ }^{6}$ were the first to debate the matter. It was pointed that about $90 \%$ of adult ADHD individuals were de novo cases (i.e. late-onset cases): they had not met childhood criteria, and differed in multiple ways from those who had. Early-onset ADHD individuals exhibited neurocognitive impairments in childhood that were largely maintained in adulthood. By contrast, in late-onset adult ADHD individuals, general intellectual ability was comparable to that of non-ADHD subjects, and neuropsychological impairments were negligible, both in childhood and in adulthood. Still, both early and late-onset groups reported marked subjective cognitive difficulties as adults, and both exhibited objective evidence of psychosocial impairment including lower income, poor credit scores, cash flow problems, poor savings behavior, more government support, and higher numbers of insurance claims ${ }^{5}$. To explain these results, Moffitt et al. raise three hypotheses: 1) Possibility of malingering, discarded due to lack of any motive for the participants to fabricate their reports. 2) Symptoms and impairment might be better explained by another disorder, suggesting that ADHD symptoms in adults might be the psychiatric equivalent of fever, a syndrome that accompanies many different illnesses and is diagnostically nonspecific but signals treatment need. 3) Late-onset adult ADHD is a genuine disorder that has unfortunately been mistaken for the neurodevelopmental disorder of ADHD because of surface similarities, and given the wrong name.

Agnew-Blais et al. ${ }^{9}$ point to three possibilities: First, individuals detected as having late-onset may have the same underlying liability for ADHD as those with childhood ADHD, but the disorder may be masked in childhood owing to protective factors, such as particularly supportive family environments or highly developed cognitive skills. In such cases, symptoms may not become impairing until the increasing challenges of later, more demanding schooling. Second, individuals detected as having late-onset may not have ADHD, but rather have another disorder with similar symptoms. They found that those with late-onset ADHD exhibit elevated rates of anxiety, depression, and marijuana and alcohol dependence. To investigate whether the late-onset group is entirely accounted for by ADHDlike symptoms caused by other disorders, they excluded individuals with diagnoses of anxiety, depression, and marijuana and alcohol dependence. Approximately onethird of the late-onset group remained after excluding individuals with these comorbidities and presented similar levels of ADHD impairment and coinformant-rated ADHD symptoms. Third, late-onset adult ADHD could be a distinct disorder. The late-onset ADHD group showed several characteristics that differ from childhood-onset ADHD, including a dissimilar sex composition (the late-onset group included more women) and lower heritability. They found that the risk of developing late-onset ADHD was similar regardless of whether the participant's twin had childhood ADHD. The extent to which the etiology differs between childhood-onset and late-onset ADHD has broad implications for the understanding of the adult ADHD population. 
Caye et al. ${ }^{8}$ affirm that their findings do not support the premise that adulthood ADHD is always a continuation of childhood ADHD. Rather, they suggest the existence of two syndromes that have distinct developmental trajectories, with a late-onset far more prevalent among adults than a childhood onset. This finding would not mean that ADHD could not be conceptualized as a neurodevelopmental disorder. Neurodevelopmental disorders may have a later onset, as is the case for schizophrenia. In addition, they point that patients with late-onset adulthood ADHD have clear impairments, and their clinical profile cannot account for only the effect of comorbidities, although comorbidities do explain a significant fraction of the detected cases.

Chandra et al. $^{7}$ are more skeptical about their findings: they recognize that their study shows that adults who do not recall onset of ADHD in childhood but report ADHD symptoms in adulthood have a profile of psychiatric comorbidity, familial transmission, and functional impairment that is similar to that seen in those meeting the age at onset diagnostic criterion. Consequently, they do not believe in the existence of a late-onset ADHD that occurs without preceding ADHD symptoms in childhood. They assert that their results suggest that the late-onset diagnosis is clinically valid, but that they cannot determine whether these people truly had later onset or could not recall their symptoms.

Kennedy et al. ${ }^{11}$ offer two possible explanations for the late-onset ADHD pattern, in the context of an adoptee sample: First, they point that late-onset cases may have a long-standing liability to ADHD, which manifested itself only after the transition to adulthood. The underlying risk could have been held in check by the buffering effect of high functioning adoptive family environments. Alternatively, this risk could be exacerbated or activated by additional stresses associated with adult life. In both cases, the effects of early adversity might only become apparent when individuals leave home and move away from protective environments (examples of a "sleeper effect"). Another possibility they raise is that late-onset ADHD is a different condition than early-onset ADHD, occurring as a secondary feature of other co-occurring conditions.

In the most recent study included in the present review, Vitola et al. ${ }^{10}$ point that the prevalence of ADHD in adults rises almost threefold if the age-of-onset criterion is not considered. In this context, careful assessment of current symptoms and relevant impairments might be key for the clinical assessment of adult ADHD.

Faraone and Biederman ${ }^{21}$, in an editorial, make reference to four of our six reviewed articles: Caye et al. ${ }^{8}$, Agnew-Blais et al. ${ }^{9}$, Moffitt et al. ${ }^{6}$ and Chandra et al. ${ }^{7}$. They assert that, as a group, the late-onset ADHD cases showed significant functional impairment. However, they caution that many of the late-onset ADHD cases appear to have had neurodevelopmental roots, and point to the possibility of subthreshold childhood ADHD ${ }^{21}$.
Finally, in a letter to the editor, Solanto ${ }^{22}$ points that the unexpected results in Caye et al. ${ }^{8}$, Agnew-Blais et al. ${ }^{9}$ and Moffitt et al. ${ }^{6}$ may reflect the method used to diagnose the disorder in children. She believes it would be premature to implement a diagnosis of late-onset ADHD without understanding more fully why clinical samples differ from the epidemiological samples reported in these studies ${ }^{22}$.

In short, potential explanations consider late-onset as: a) symptoms of another disorder, a syndrome that accompanies many different illnesses ${ }^{6,9,11}$; b) a genuine disorder/distinct syndrome $\mathrm{e}^{6,8,9}$, including its own hereditary patterns $^{9}$; c) having the same underlying liability of earlyonset, including same familial transmission ${ }^{7}$, but symptoms become impairing later in life, because of increasing $\operatorname{adversities}^{7,9,11}$.

Our review identified some characteristics of late-onset ADHD that distinguish it from the earlyonset symdromme, including difference in gender distribution with increased prevalence in females, neglectable impairment on cognition; increased levels of anxiety, depression and alcohol dependence and lower heritability. Such characteristics offers some support for the discriminant validity for late-onset ADHD. However, as it has been pointed, an in advance hypothesis should contain which measure of a construct and which criterion variables will be checked, based on the theoretic fundamentals of the disease. Also, most data included in this review are based on categorical variables and validation analysis is based on correlations that should have its minimal acceptable magnitude established a priori $^{13}$.

\section{CONCLUSIONS}

Taking into account all previous considerations, we can conclude that late-onset adult ADHD may be a valid diagnosis, and that clinicians should not neglect treatment of ADHD in adults because of the age-of-onset criterion. However, there is still a lot of controversy among researchers and practitioners. Specially, beyond the studies of validity, a consistent theory for late-onset ADHD supporting it as a different syndrome, without a neurodevelopmental origin, is missing. Nevertheless, as mention before, it is completely possible for a neurodevelopmental disorder to show symptoms only later in adolescence or adulthood. This converges to an ongoing discussion in Psychiatry about categorical versus dimensional approach for mental disorders. There is a tendency to consider mental disorders as extreme cases of broadly distributed traits, so late-onset ADHD could be a less severe form of the classic early-onset ADHD, although confounding factors should be better studied before accepting this new paradigm. But even if this paradigm could be properly rejected with further studies, with thorough and careful analysis, at the very least least it raises the question: could adults with ADHDlike symptoms explained by other disorders benefit from treatment similarly as ADHD individuals? 
Xavier M, et al. Is late-onset Attention Deficit Hyperactivity Disorder (ADHD) a valid diagnosis in adults?

Participação dos autores no texto: Xavier M - Escolha do tema a ser estudado, seleção dos artigos, estruturação da revisão e escrita do texto final; Medeiros AS e Campos L - Escolha do tema a ser estudado, seleção dos artigos e estruturação da revisão; Fráguas R Orientação e supervisão na escolha do tema a ser estudado, seleção dos artigos, estruturação da revisão e escrita do texto final.

\section{REFERENCES}

1. Thapar A, Cooper M. Attention deficit hyperactivity disorder. Lancet. 2016;387(10024):1240-50. http://dx.doi. org/10.1016/s0140-6736(15)00238-x.

2. Association AP. Diagnostic and Statistical Manual of Mental Disorders. 4th ed. Washington: American Psychiatric Association; 1994. Available from: http:// dsm.psychiatryonline.org/doi/pdf/10.1176/appi. books.9780890420614.dsm-iv.

3. Association AP. Diagnostic and Statistical Manual of Mental Disorders. 5th ed. Washington: American Psychiatric Association; 2013. Available from: http:// dsm.psychiatryonline.org/doi/book/10.1176/appi. books.9780890425596.

4. Lin Y-J, Lo K-W, Yang L-K, Gau SS-F. Validation of DSM5 age-of-onset criterion of attention deficit/hyperactivity disorder (ADHD) in adults: Comparison of life quality, functional impairment, and family function. 2015;47:48-60. https://doi.org/10.1016/j.ridd.2015.07.026.

5. Xavier-Castellanos F. Is adult-onset ADHD a distinct entity? Am J Psychiatry. 2015;172(10):929-31. doi: 10.1176/appi. ajp.2015.15070988.

6. Moffitt TE, Houts R, Asherson P, Belsky DW, Corcoran DL, Hammerle M, et al. Is adult ADHD a childhoodonset neurodevelopmental disorder? Evidence from a Four-decade longitudinal Cohort Study. Am J Psychiatry. 2015;172(10):967-77. doi: 10.1176/appi. ajp.2015.14101266.

7. Chandra S, Biederman J, Faraone SV. Assessing the Validity of the Age at Onset Criterion for Diagnosing ADHD in DSM-5. J Atten Disord. 2016. pii: 1087054716629717. doi: $10.1177 / 1087054716629717$.

8. Caye A, Rocha TBM, Anselmi L, Murray J, Menezes AMB, Barros FC, et al. Attention-deficit/hyperactivity disorder trajectories from childhood to young adulthood evidence from a birth cohort supporting a late-onset syndrome. JAMA Psychiatry. 2016;73(7):705-12. doi: 10.1001/ jamapsychiatry.2016.0383.

9. Agnew-Blais JC, Polanczyk GV, Danese A, Wertz J, Moffitt TE, Arseneault L. Evaluation of the Persistence, remission, and emergence of attention-deficit/hyperactivity disorder in young adulthood. JAMA Psychiatry. 2016;73(7):713-20. doi: 10.1001/jamapsychiatry.2016.0465.

10. Vitola ES, Bau CHD, Salum GA, Horta BL, Quevedo L, Barros FC, et al. Exploring DSM-5 ADHD criteria beyond young adulthood: Phenomenology, psychometric properties and prevalence in a large three-decade birth cohort. Psychol Med. 2017;47(4):744-54. doi: 10.1017/ S0033291716002853.

11. Kennedy M, Kreppner J, Knights N, Kumsta R, Maughan B, Golm D, et al. Early severe institutional deprivation is associated with a persistent variant of adult attention-deficit/ hyperactivity disorder: clinical presentation, developmental continuities and life circumstances in the English and Romanian adoptees study. J Child Psychol Psychiatry. 2016;57(10):1113-25. doi: 10.1111/jcpp. 12576.
12. Aboraya A, France C, Young J, Curci K, LePage J. The Validity of Psychiatric Diagnosis Revisited: The Clinician's Guide to Improve the Validity of Psychiatric Diagnosis. Psychiatry (Edgmont). 2005;2(9):48-55. Available from: https:/www.ncbi.nlm.nih.gov/pmc/articles/PMC2993536/.

13. Westen D, Rosenthal R. Quantifying construct validity: Two simple measures. J Personality Social Psychol. 2003;84(3):608. doi: 10.1037/0022-3514.84.3.608.

14. Jablensky A. Psychiatric classifications: validity and utility. World Psychiatry. 2016;15(1):26-31. doi: 10.1037/00223514.84.3.608.

15. Green SM, Loeber R, Lahey BB. Stability of mothers' recall of the age of onset of their child's attention and hyperactivity problems. J Am Acad Child Adolesc Psychiatry. 1991;30(1):135-7. https://doi.org/10.1097/00004583199101000-00020.

16. Loney J, Ledolter J, Kramer JR, Volpe RJ. Retrospective ratings of ADHD symptoms made at young adulthood by clinic-referred boys with ADHD-related problems, their brothers without ADHD, and control participants. Psychol Assessment. 2007;19(3):269. doi: 10.1037/10403590.19.3.269.

17. Faraone SV, Biederman J, Spencer T, Mick E, Murray $\mathrm{K}$, Petty C, et al. Diagnosing adult attention deficit hyperactivity disorder: are late onset and subthreshold diagnoses valid? Am J Psychiatry. 2006;163(10):1720-9; quiz 1859. doi: 10.1176/ajp.2006.163.10.1720.

18. Faraone SV, Biederman J, Doyle A, Murray K, Petty C, Adamson JJ, et al. Neuropsychological Studies of late onset and subthreshold diagnoses of adult attention-deficit/ hyperactivity disorder. 2006;60(10):1081-7. doi: 10.1016/j. biopsych.2006.03.060.

19. Caye A, Swanson J, Thapar A, Sibley M, Arseneault L, Hechtman L, et al. Life Span studies of ADHD-conceptual challenges and predictors of persistence and outcome. Curr Psychiatry Rep. 2016;18(12):111. http://dx.doi.org/10.1007/ s11920-016-0750-x.

20. Sibley MH, Mitchell JT, Becker SB. Method of adult diagnosis influences estimated persistence of childhood ADHD: a systematic review of longitudinal studies. Lancet Psychiatry. 2016;3(12):1157-65. doi: 10.1016/S22150366(16)30190-0.

21. Faraone SV, Biederman J. Can Attention-Deficit/ Hyperactivity Disorder Onset Occur in Adulthood? JAMA Psychiatry. 2016;73(7):655-6. doi:10.1001/ jamapsychiatry.2016.0400.

22. Solanto MV. Child vs Adult Onset of Attention-Deficit/ Hyperactivity Disorder. JAMA Psychiatry. 2017;74(4):421. doi: 10.1001/jamapsychiatry.2016.2741.

Recebido em: 02.07.17

Aceito em: 19.02.18 